\title{
Immunological characterisation of plasminogen activators in the human vessel wall
}

\author{
H LJUNGNER, ${ }^{*}$ L HOLMBERG, † A KJELDGAARD, IM NILSSON,§ B ÅSTEDT**
}

From the ${ }^{*}$ Department of Surgery, the $†$ Department of Paediatrics, University of Lund, Malmö General Hospital, Malmö, the $\ddagger$ Department of Obstetrics and Gynaecology, Huddinge Hospital, Huddinge, the $\S$ Department for Coagulation Disorders, University of Lund, Malmö General Hospital, Malmö, and the ${ }^{* *}$ Department of Obstetrics and Gynaecology, University Hospital, Lund, Sweden

SUMMARY A histochemical technique was used to identify the activity of the plasminogen activator (PA) in the vessel wall of veins. Antibodies against melanoma cell activator and urokin- $-\circ$ ase (UK), both raised in goats, were mixed into the fibrin film. The PA activity was quenched by $\vec{\circ}$ the antibodies against melanoma activator but remained unchanged when antibodies against UK, $\stackrel{\circ}{\circ}$ or an IgG preparation of normal goat serum, was mixed in the fibrin film. The results of this study? show that the PA activity in the vein vessel wall is immunologically similar to or identical to the $\vec{c}$ PA derived from melanoma cells which has previously been shown to cross-react with the tissue-like PA. No UK-like activity was present in the vessel wall.

The fibrinolytic system is activated by plasminogen activators localised in tissues, in blood and in different fluids of the human body. Two types of plasminogen activator (PA) have been recognised, blood/tissue-like and urokinase-like.

The blood vessels are considered to be the main source of blood and tissue PA. ${ }^{2}$ Using histochemical techniques, it has been demonstrated that PA is confined mainly to vasa vasorum and to the intima,${ }^{1-3}$ from which the release of this activator occurs. ${ }^{4-6}$ There are also inhibitors to the fibrinolytic system in the vessel wall, ${ }^{7}$ which mainly inhibit urokinase. $^{8}$

Urokinase (UK), the main activator in urine, is produced not only in the kidney and urinary outflow pathways, ${ }^{9}$ but is also present in carcinomas and tumour derived cell-lines ${ }^{1011}$ in normal uterine endometrium ${ }^{12}$ and in various fetal organs. ${ }^{13}$

Blood and tissue PA differ from UK in terms of immunological reaction, enzymatic activity and molecular weight. ${ }^{13-15}$ Blood PA can be increased by venous occlusion, physical exercise and various substances such as adrenaline, nicotinic acid, vasopressin and its synthetic analogue DDAVP. ${ }^{16}$ Tissue PA is responsible for the fibrinolytic activity induced in human blood by the above mentioned stimuli. 617 However, UK might be responsible for some of the spontaneous fibrinolytic activity in plasma. ${ }^{18} 19$

Accepted for publication 6 April 1983
We report here the quenching of PA activity in $\overrightarrow{0}$ the vein vessel wall by monospecific antibodi against UK and PA of the blood/tissue-like type.

Material and methods

DETERMINATION OF PA ACTIVITY IN THE VESSEL WALL

Biopsy specimens, about $3 \mathrm{~cm}$ long, obtained from the great saphenous vein during surgery, were hermetically sealed in parafilm and immediately frozen to $-70^{\circ} \mathrm{C}$. PA activity was determined with a modification of Todd's histochemical fibrin slide techni-용 que $^{1}$ as described in detail by Pandolfi et al. ${ }^{2}$ Briefly, sections $8 \mu \mathrm{m}$ thick, were cut in a cryostat micro- 3 . tome, collected on glass slides and covered with a $\delta$ thin fibrin film rich in plasminogen. The film was obtained by mixing bovine fibrinogen $(1 \%)$ in phos- 0 phate buffer $(\mathrm{pH} 7 \cdot 8)$ which was coagulated with thrombin (Topostasine, Roche). After a preincubation period of $30 \mathrm{~min}$ at a temperature of $19^{\circ} \mathrm{C}$, the $\frac{}{\mathrm{N}}$ fibrin slides were incubated at $37^{\circ} \mathrm{C}$ in a moist $\odot$ chamber for 20 and $30 \mathrm{~min}$ and after that fixed and $N$ stained. PA activity in the sections was reflected as N clear zones of lysis, surrounded by dark stained fibrin film.

TISSUE PA AND ANTISERUM TO THE MELANOMA CELL ACTIVATOR

Pure tissue PA was obtained from the culture 
medium of a cultivated melanoma cell line (provided by Dr D Collen). It is very similar to or identical with human tissue PA from uterine tissue. ${ }^{15}$ The cells were first grown to confluence in medium M 199 containing $10 \% \mathrm{vol} / \mathrm{vol}$ fetal calf serum and then for several passages in serum-free medium, which was harvested. The activator was purified by immunosorbent chromatography using antibodies against porcine tissue activator essentially as described for the purification of human tissue PA. The melanoma activator was absorbed from the medium to the immunosorbent and eluted with $\mathrm{KSCN}$. The eluted material was purified further by chromatography on arginine-Sepharose and by gel filtration. ${ }^{20}$ The final product was electrophoretically homogeneous.

\section{ANTISERUM TO TISSUE PA}

Antiserum was raised in a goat by two injections, the second three weeks after the first, of $150 \mu \mathrm{g}$ purified activator, emulsified with Freund's complete adjuvant. The injections were given subcutaneously at different sites in the back. The antiserum gave one precipitation line with melanoma conditioned culture medium in gel diffusion. The melanoma activator showed an immunological reaction of complete identity with tissue PA purified from human uterine tissue. IgG from the antiserum and normal goat serum was purified by ammonium sulphate precipitation, DEAE-Sephadex chromatography and Sephadex G-200 gel filtration as earlier described. ${ }^{17}$ The IgG completely neutralised plasminogen activator activity in plasma and ordinary euglobulin precipitates. One milligram total IgG completely quenched the activity of $0.07 \mathrm{mg}$ pure melanoma activator.

\section{ANTISERUM TO UROKINASE}

UK was obtained from Lövens, Copenhagen (10000 Ploug units) and further purified by $p$-aminobenzamidine-Sepharose chromatography ${ }^{21}$ and low molecular weight $\left(M_{r} 31000\right)$ and high molecular weight $\left(M_{\mathrm{r}} 54000\right)$ urokinase separated by gel filtration. ${ }^{22}$ Antiserum against low molecular weight urokinase was raised in a goat as described for tissue PA and IgG from the antiserum prepared in the same way.

\section{QUENCHING OF PA ACTIVITY}

Quenching of PA activity was studied using IgG antibodies against melanoma activator (anti-MA), urokinase (anti-UK), and an IgG preparation from a control goat (control IgG). Antibodies were incorporated into the fibrin film by mixing the same concentration of the IgG fractions of anti-MA, anti-UK or control IgG with the fibrinogen solution before

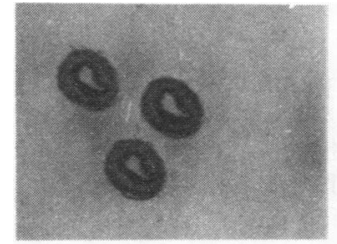

Anti MA

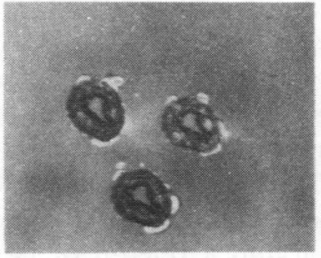

Control lgG

(a) Activity after 20 min incubation

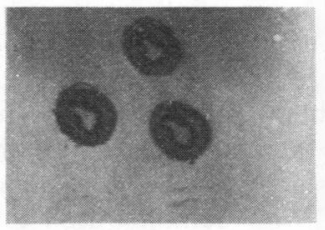

Anti MA

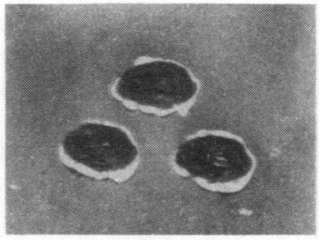

Control lgG

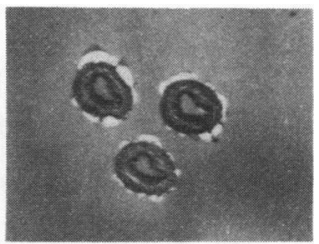

Anti UK

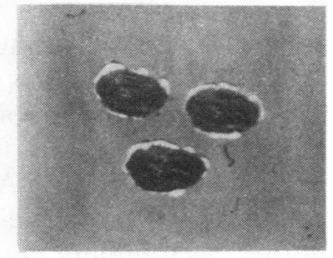

Control

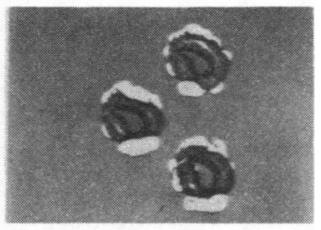

Anti UK

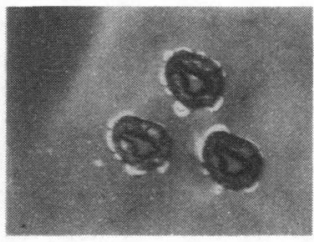

Control (b) Activity after 30 min incubation

$P A$ activity determined according to a histochemical fibrin slide technique as seen by the naked eye

the addition of thrombin.

\section{Results}

As seen from the Figure, the PA activity was quenched by the antibodies against melanoma activator (anti-MA). Neither anti-UK nor IgG from the control goat (control IgG) inhibited the activity, and the results were independent of the length of incubation periods. The activity was the same in the fibrin slides coated with anti-UK, or control IgG, as well as in the control slides without any IgG. PA activity was solely localised to the adventitia of the vessel wall. Similar results were obtained from one corresponding vessel in three different individuals. 


\section{Discussion}

The two main PA of the organism are blood/tissue PA, and UK. In blood there is an additional mechanism activating the fibrinolytic system, which is dependent on factor XII, pre-kallikrein and high molecular weight kininogen (reviewed by Murano $^{23}$ ). PA derived from tissues has a strong affinity for fibrin ${ }^{14}$ and is immunologically related to the vascular PA, which has been partly purified from cadaveric vein perfusates. ${ }^{24-26}$

UK-like material has been found in several tissues and fluids. ${ }^{1213}$ In rabbit endothelial cultures Loskutoff and Edgington ${ }^{5}$ found a release of tissue-like as well as UK-like PA. Certain human cell lines produce either tissue-like or UK-like PA, or both. ${ }^{27}{ }^{28}$ Holmberg et al $^{13}$ found a release of both UK-like and tissue-like PA in cultures of most human fetal organs, but only of tissue-like PA in cultures of aorta explants. It is, therefore, debatable whether or not UK-like PA is partially responsible for the spontaneous fibrinolytic activity of the blood.

Recently Rijken et al $^{6}$ demonstrated that PA activity, released into the blood after venous occlusion or physical exercise, is related to PA of the tissue-like type. These results have been corroborated by Holmberg et al ${ }^{17}$ who demonstrated that the fibrinolytic activity of human blood induced by venous occlusion or DDAVP was quenched by antibodies to the melanoma plasminogen activator. UK-like material measured by radioimmunoassay, was not released by DDAVP, nor was the intrinsic fibrinolytic system of plasma affected. Furthermore, Asstedt ${ }^{29}$ showed that there was no release of UKlike activity after venous occlusion. In the present study the PA activity of the vein vessel wall was exclusively tissue-like PA because it was completely quenched by anti-MA but not by anti-UK, nor by goat IgG. This is in agreement with the above mentioned studies that PA released from the vessel wall is of the tissue-like type.

Releasing the plasminogen activator content in the vein vessel wall into the blood stream is the most important function of the fibrinolytic defence system, and is one which has been shown to be defective in many patients suffering from recurrent thrombosis. ${ }^{30}$ The present results bear this out and demonstrate that the plasminogen activator contained in the vessel wall is of the same type as that released by a variety of stimuli.

This investigation was supported by grants from the Swedish Medical Research Council (17X-04523, 19X-04997, 19X-00087).

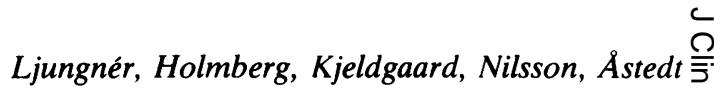

References

1 Todd AS. The histological localisation of fibrinolysin activator. $J$ 으 Pathol Bacteriol 1959;78:281-3.

${ }^{2}$ Pandolf $M$, Robertson B, Isacson S, Nilsson IM. Fibrinolytic $\overrightarrow{\overline{\vec{A}}}$ activity of human veins in arms and legs. Thromb Haemost 1968;20:247-56.

${ }^{3}$ Yao JST, Bergan JJ, Kwaan HC. Quantitation of fibrinolytic $\frac{\bar{\sigma}}{\bar{\sigma}}$ activity in venous and prosthetic arterial grafts. Arch Surg 1974;109: 163-7.

- Astedt B, Pandolfi M. On release and synthesis of fibrinolytic $\frac{\varrho}{0}$ activators in human organ cultures. Rev Eur Etud Clin Biol 1972;17:261-7.

${ }^{5}$ Loskutoff DJ, Edgington TS. Synthesis of a fibrinolytic activator and inhibitor by endothelial cells. Proc Natl Acad Sci USA 1977;74:3903-7.

6 Rijken DC, Wijngaards G, Welbergen J. Relationship between tissue plasminogen activator and the activators in blood and $\frac{\Omega}{0}$ vascular wall. Thromb Res 1980;18:815-30.

7 Noordhoek-Hegt V. Relations between activation and inhibition of fibrinolysis in the walls of human arteries and veins. Thromb Haemost 1977;38:407-19.

${ }^{8}$ Loskutoff DJ, Edgington TS. An inhibitor of plasminogen $\stackrel{P}{\rightarrow}$ activator in rabbit endothelial cells. $J$ Biol Chem $1981 ; 256: 4142-5$.

9 Barlow GH, Lazer LV. Characterization of the plasminogen activator isolated from human embryo kidney cells: compari- $\rho$ son with urokinase. Thromb Res 1972;1:201-7.

${ }^{10}$ Astedt B, Holmberg L. Immunological identity of urokinase and $\frac{0}{(\mathbb{D}}$ ovarian carcinoma plasminogen activator released in tissue $\frac{\mathbb{D}}{3}$ culture. Nature 1976;261:595-7.

$"$ Vetterlein D, Bell TE, Young PL, Roblin R. Immunological $\stackrel{\mathbb{D}}{\text { - }}$ quantitation and immunoadsorption of urokinase-like plass- $\vec{C}$ minogen activators secreted by human cells. J Biol Ch@ 1980;255:3665-72.

12 Casslén B. Proteinases and proteinase inhibitors in uterine fut with special reference to IUD-users. Acta Obstet Gynec్l인 Scand 1981; suppl 98:18.

${ }^{13}$ Holmberg L, Kristoffersson A-C, Lecander I, Wallén P, Åstedt B. Immunoradiometric quantification of tissue plasminogen activator secreted by fetal organs. Comparison with urokinase. () Scand J Clin Lab Invest 1982;42:347-53.

14 Thorsen S, Glas-Greenwalt P, Astrup T. Differences in the bind- $\overrightarrow{\bar{O}}$ ing to fibrin of urokinase and tissue plasminogen activator. 3

Thromb Haemost 1972;28:65-74.
is Rijken DC, Collen D. Purification and characterization of the plasminogen activator secreted by human melanoma cells in culture. J Biol Chem 1981;256:7035-41.

${ }^{16}$ Mannucci PM, Åberg M, Nilsson IM, Robertson B. Mechanism? of plasminogen activator and factor VIII increase after vasoactive drugs. Br J Haematol 1975;30:81-93.

${ }^{17}$ Holmberg L, Nilsson IM, Wallén P, Astedt B. Studies of the blood plasminogen activator induced by $1-\frac{3}{3}$ desamino-8-D-arginine-vasopressin with observations in von Willebrand's disease. Proc Soc Exp Biol Med 1982;170:음 126-32.

18 Shakespeare $M$, Wolf $P$. The demonstration of urokinase antigen in whole blood. Thromb Res 1979;14:825-35.

19 Wijngaards G, Kluft C, Groenevald E. Demonstration of urokinase-related fibrinolytic activity in human plasma. $\mathrm{Br} \mathrm{J}$ Haematol 1982;51:165-9.

${ }^{20}$ Wallén $P$, Rånby $M$, Bergsdorf $N$, Kok P. Purification and N characterization of tissue plasminogen activator: on the occurrence of two different forms and their enzymatic proper $\frac{\sigma}{<}$ ties. In: Davidson JF, Nilsson IM, Åstedt B, eds. Progress ino fibrinolysis. Edinburgh, London, Melbourne, New York: $\frac{\complement}{\mathscr{D}}$ Churchill-Livingstone 1981;5:16-23.

${ }^{21}$ Holmberg L, Bladh B, Astedt B. Purification of urokinase by affinity chromatography. Biochem Biophys Acta 1976;445: 215-22. 
${ }^{22}$ Holmberg L, Lecander I, Persson B, Àstedt B. An inhibitor from placenta specifically binds urokinase and inhibits plasminogen activator released from ovarian carcinoma in tissue culture. Biochim Biophys Acta 1978;544:128-37.

${ }^{23}$ Murano G. The "Hageman" connection: Interrelationships of blood coagulation, fibrino(geno)lysis, kinin generation and complement activation. Am J Hematol 1978;4:409-17.

${ }^{24}$ Aoki N. Preparation of plasminogen activator from vascular trees of human cadavers. J Biochem 1974;75:731-41.

${ }^{25}$ Binder BR, Spragg J, Austen KF. Purification and characterization of human vascular plasminogen activator derived from blood vessel perfusates. J Biol Chem 1979;254:1998-2003.

${ }^{26}$ Aasted B. Purification and characterization of human vascular plasminogen activator. Biochim Biophys Acta 1980;621: 241-54.
${ }^{27}$ Vetterlein D, Young PL, Bell TE, Roblin R. Immunological characterization of multiple molecular weight forms of human cell plasminogen activators. J Biol Chem 1979;254:575-8.

${ }^{28}$ Roblin R, Young PL. Dexamethasone regulation of plasminogen activator in embryonic and tumor-derived human cells. Cancer Res 1980;40:2706-13.

29 Astedt B. No cross reaction between circulating plasminogen activator and urokinase. Thromb Res 1979;14:535-9.

${ }^{30}$ Nilsson IM, Isacson S. New aspects of the pathogenesis of thrombo-embolism. Progr Surg 1973;11:46-68.

Requests for reprints to: Dr $\mathbf{H}$ Ljungnér, Department for Coagulation Disorders, University Hospital, S Förstadsga$\tan 101$, S-214 01 Malmö, Sweden.

\section{The August 1983 issue}

\section{THE AUGUST 1983 ISSUE CONTAINS THE FOLLOWING PAPERS}

Review article

Formaldehyde in pathology departments RP CLARK

A data processing system adapted to the special needs of the emergency laboratory D NEUMEIER, $H$ SATOR, GE RINDFLEISCH, M KNEDEL

Computer programs in cytology reporting and record keeping KV SWETTENHAM, CD NICKOLS, CL BERRY

The synovium and synovial fluid in multicentric reticulohistiocytosis-a light microscopic, electron microscopic and cytochemical analysis of one case AJ FREEMONT, CJP JONES, J DENTON

Changes in the Paneth cell population of human small intestine assessed by image analysis of the secretory granule area MARGARET E ELMES, J GWYN JONES, MR STANTON

Blood group antigens in the normal and neoplastic bladder epithelium SUSAN J THORPE, P ABEL, G SLAVIN, TEN FEIZI

Demonstration of light chain monotypia in B cell non-Hodgkin's lymphomas using unfixed freezedried and formalin-fixed trypsinised paraffin sections Z NEMES, $V$ THOMÁZY, G SZEIFERT

Calcium pyrophosphate dihydrate (CPPD) deposition in ochronotic arthropathy $J$ McCLURE, PS SMITH, AMANDA A GRAMP

Use of the cryostat section in electron microscopy P NORRIS, DWR GRIFFITHS

Increased transfer of iron to the fetus after total dose infusion of iron dextran during pregnancy $D$ BINGHAM, MM KHALAF, G WALTERS, JT WHICHER
Differential effect of detergents on the alkaline denaturation of haemoglobin in maternal and fetal blood, with particular reference to Triton X-100 CG DUCK-CHONG

Analysis of the complexity of the multimeric structure of factor VIII related antigen/von Willebrand protein using a modified electrophoretic technique MS ENAYAT, FGH HILL

Faecal carriage rate of Aeromonas hydrophila SALLY E MILLERSHIP, SR CURNOW, B CHATTOPADHYAY The value of screening blood donors for antibody to hepatitis B core antigen AC ARCHER, BJ COHEN, PP MORTIMER

A miniaturised and simplified technique for typing and subtyping herpes simplex virus JM DARVILLE

Growth hormone and malignancy GS ANDREWS

Angiotensin-converting enzyme and its clinical significance - a review PR STUDDY, RUTH LAPWORTH, R BIRD

Quality assessment of blood glucose monitors in use outside the hospital laboratory RF DRUCKER, DRR WILLIAMS, CP PRICE

\section{Technical method}

A new bone marrow aspiration needle to overcome the sampling errors inherent in the technique of bone marrow aspiration A ISLAM

Letters to the Editor

Book reviews

Some new titles

Notice

Copies are still available and may be obtained from the PUBLISHING MANAGER, BRITISH MEDICAL ASSOCIATION, TAVISTOCK SQUARE, LONDON WC1H 9JR. Price $£ 5.00$, including postage. 